\title{
Paleolimnological Reconstructions of Holocene Environments and Climate from Lake Lyadhej-To, Ural Mountains, Northern Russia
}

\author{
Author(s): Holger Cremer, Andrei Andreev, Hans-Wolfgang Hubberten, and Frank Wischer \\ Source: Arctic, Antarctic, and Alpine Research, 36(2):147-155. 2004. \\ Published By: Institute of Arctic and Alpine Research (INSTAAR), University of Colorado \\ DOI: http://dx.doi.org/10.1657/1523-0430(2004)036[0147:PROHEA]2.0.CO;2 \\ URL: http://www.bioone.org/doi/full/10.1657/1523-0430\%282004\%29036\%5B0147\%3APROHEA \\ $\% 5 \mathrm{D} 2.0 . \mathrm{CO} \% 3 \mathrm{~B} 2$
}

BioOne (www.bioone.org) is a nonprofit, online aggregation of core research in the biological, ecological, and environmental sciences. BioOne provides a sustainable online platform for over 170 journals and books published by nonprofit societies, associations, museums, institutions, and presses.

Your use of this PDF, the BioOne Web site, and all posted and associated content indicates your acceptance of BioOne's Terms of Use, available at www.bioone.org/page/terms of use.

Usage of BioOne content is strictly limited to personal, educational, and non-commercial use. Commercial inquiries or rights and permissions requests should be directed to the individual publisher as copyright holder. 


\section{Paleolimnological Reconstructions of Holocene Environments and Climate from Lake Lyadhej-To, Ural Mountains, Northern Russia}

\author{
Holger Cremer \\ Utrecht University, Department of \\ Palaeoecology, Laboratory of Palaeobotany \\ and Palynology, Budapestlaan 4, $3584 \mathrm{CD}$ \\ Utrecht, The Netherlands. \\ h.cremer@bio.uu.nl
}

\section{Andrei Andreev, Hans-Wolfgang Hubberten, and Frank Wischer}

Alfred Wegener Institute Foundation for Polar and Marine Research, Research Department Potsdam, Telegrafenberg A43, 14473 Potsdam, Germany.

\begin{abstract}
A sediment core recovered in Lake Lyadhej-To at the northwestern edge of the Ural Mountains reflects the complete Holocene environmental history from $\sim 11,000$ cal. yr B.P. Five limnological episodes are identified in the diatom and geochemical records. The initial lake stage, Episode I ( 11,000-10,850 cal. yr B.P.) is characterized by the absence of biogenic production and a high influx of clastic sediments. Episode II ( 10,850-8650 cal. yr B.P.) is characterized by ice-free conditions during summer, highest bioproductivity, strong growth of planktic diatoms and anoxic bottom waters. This period represents the Holocene climatic optimum. Deterioration of climatic conditions commenced in Episode III ( $\sim 8650-7000$ cal. yr B.P.) as indicated by distinctly lower bioproductivity and longer persistence of winter ice on the lake. During Episode IV ( 7000-2500 cal. yr B.P.), the diatom and pollen records indicate that temperatures were cool and the growing season was short. Finally, in Episode $V$ ( $\sim 2500$ cal. yr B.P. to present), limnological conditions, indicated by increased organic carbon and diatom deposition, initially suggest improved conditions followed by a return to modern conditions beginning $\sim 500 \mathrm{cal}$. yr B.P. The pollen stratigraphy from Lake Lyadhej-To is consistent with other paleoclimatic records from northern Eurasia, confirming rapid postglacial warming, the presence of dense tree forests during the climatic optimum, and finally a gradual southward retreat of the treeline towards its modern location.
\end{abstract}

\section{Introduction}

The southward extent of the Barents-Kara Sea Ice Sheet during the Last Glacial Maximum (LGM) has been a matter of discussion for some time (Mangerud et al., 2002, and references therein). During the past years many efforts have been made to clarify the position of the ice-sheet margin during the Weichselian. The most recent geomorphological and chronological results suggest a continental shelf position of the ice-sheet margin during the LGM and, consequently, an ice-free northern Russian mainland including the Pechora Lowland and the West Siberian Plain (Mangerud et al., 2001, 2002). A detailed study of terrestrial sections recovered from ice-dammed paleolake Komi in the region west of the Ural Mountains showed that maximum ice-sheet extensions occurred during the early and middle Weichselian and that the region was ice free during the Late Weichselian (Mangerud et al., 2001).

However, in northern Russia little data, particularly those including diatoms, exist on the present limnology and late Quaternary paleolimnology from areas that were possibly affected by ice. The few recently published diatom studies include (1) Laing and Smol (2000), who compared the modern diatom flora and limnology from sites in the Pechora River, Taimyr and Lena River regions; (2) Kienel (1999) and Kienel et al. (1999), who described Holocene diatom successions and their paleoecology from the North Siberian Lowland (Taimyr region); and (3) Michelutti et al. (2001), who studied the effects of mining activities on diatom assemblages in the Noril'sk region (southern Taimyr region).

Here we report on the postglacial climatic and environmental history of Lake Lyadhej-To, located at the northwestern tip of the Ural Mountains (Fig. 1), with particular focus on the diatom flora and its Holocene development. We recovered a 11.8-m-long sediment core, which consists of a basal 5-m-thick, highly consolidated till and an overlying 7-m-thick layer of lacustrine sediments, from this High Arctic lake (Hermichen et al., 2000). Geochemical and chronological analyses on this core showed that the basal till originated from the middle Weichselian Barents-Kara Sea Ice Sheet, confirming that the region was ice free during the LGM. The lacustrine sequence of this core represents the entire Holocene history of Lake Lyadhej-To (Wischer et al., 2001).

\section{SITE DESCRIPTION}

Lake Lyadhej-To $\left(68^{\circ} 15^{\prime} \mathrm{N}, 65^{\circ} 47^{\prime} \mathrm{E}\right)$ is located in the Western Siberian lowlands on the northwestern edge of the Ural Mountains at the margin of the early/middle Weichselian Barents-Kara Sea Ice Sheet, the so-called Markhida Line (Fig. 1; Astakhov et al., 1999; Mangerud et al., 2001). The lake is located $150 \mathrm{~m}$ a.s.l., has a surface area of $\sim 4 \mathrm{~km}^{2}$ and is subdivided into two basins with a maximum water depth of $26 \mathrm{~m}$ (southern basin) and $21 \mathrm{~m}$ (northern basin), respectively (Fig. 1). The lake was visited twice, once in 1998 (end July) and again in 1999 (mid to end April), to carry out hydrological and geophysical/sedimentological surveys (Hermichen and Wischer, 1999; Hermichen et al., 2000). Both basins have a similar hydrology as indicated by the temperature, oxygen, $\mathrm{pH}$, and conductivity profiles taken in July 1998 (Table 1). Lake Lyadhej-To is an oligotrophic lake with relatively low ionic content and is circumneutral to slightly alkaline. The temperature profiles in Table 1 point to the occurrence of a weak thermic stratification. The relatively intense solar radiation during summer results in a metalimnion between about 7 and $14 \mathrm{~m}$ water depth. During the spring 1999 expedition the lake was covered by $\sim 1.9 \mathrm{~m}$ of ice and the water column below the ice had a temperature slightly above $0^{\circ} \mathrm{C}$ (Hermichen et al., 2000). Lake Lyadhej-To has 


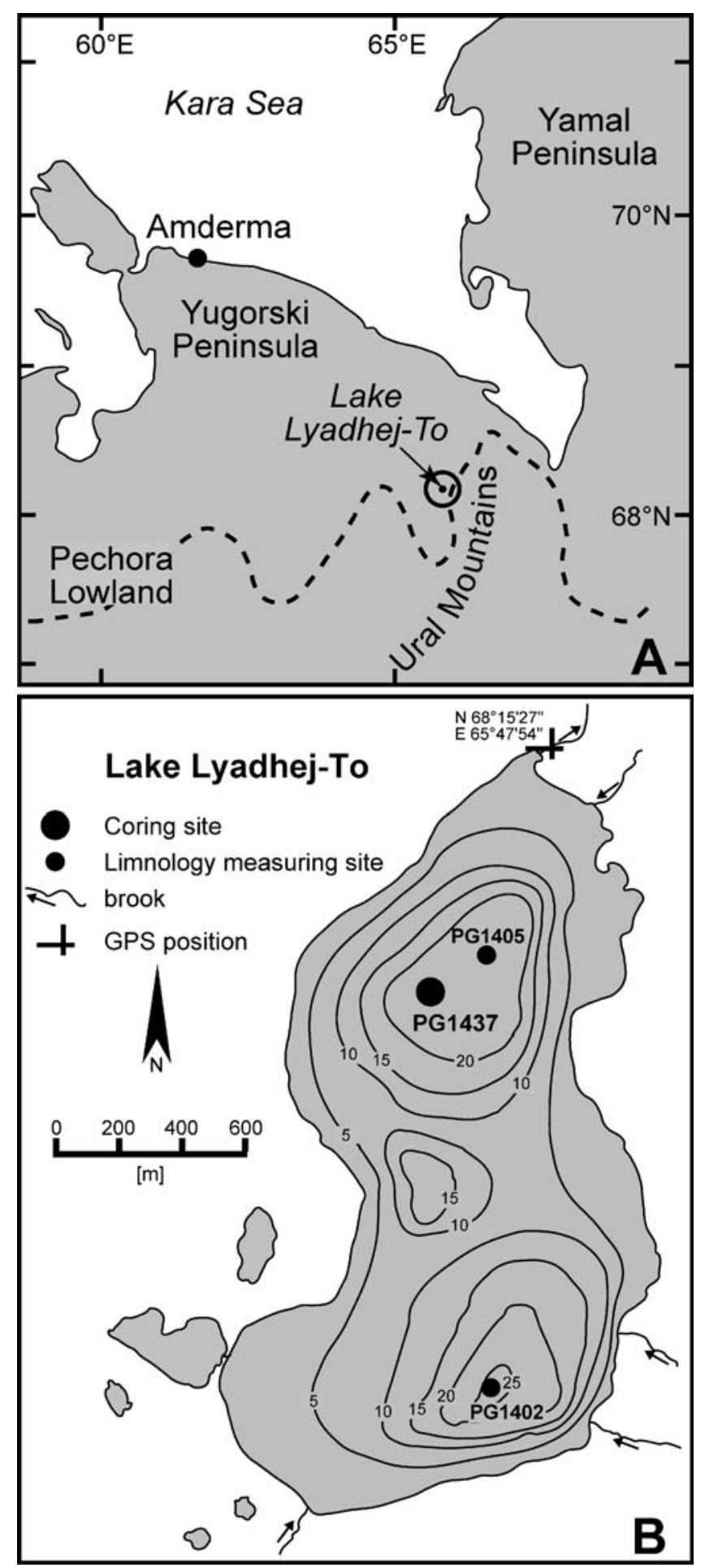

FIGURE 1. Geography of the study area. A. Map of Yogorski Peninsula, northern Russia, and adjacent regions. The dashed line is the so-called Markhida Line which marks the early to middle Weichselian ice-sheet limit in the region (after Astakhov et al., 1999). B. Bathymetry and sampling sites in Lake Lyadhej-To. The bathymetry was surveyed by single-point measurements along several longitudinal and latitudinal transects.

several inflows into the southern basin and one major outflow at the northern end of the lake (Fig. 1).

The geology of the region is characterized by igneous Paleozoic rocks that are overlain by 3000- to 6000-m-thick Mesozoic-Cenozoic sedimentary deposits and 50- to 300-m-thick Quaternary sediments of
TABLE 1

Vertical temperature, conductivity, $\mathrm{pH}$-values and oxygen concentration profiles at sites PG1402 and PG1405 in Lake Lyadhej-To (taken from Hermichen and Wischer, 1999)

\begin{tabular}{lrccc}
\hline \hline \multicolumn{2}{c}{ Temperature Conductivity } & $\mathrm{pH}$ & $\begin{array}{c}\text { Oxygen } \\
\text { Water depth }[\mathrm{m}]\end{array}$ \\
{$\left[{ }^{\circ} \mathrm{C}\right]$} & {$\left[\mu \mathrm{S} \mathrm{cm}^{-1}\right]$} & $\left.\mathrm{concentration}^{-1}\right]$ \\
\hline Site PG1402, southern basin & & & & \\
0.1 & 16.3 & 62 & 7.8 & 9.6 \\
5 & 16.4 & 68 & 8.0 & 8.8 \\
10 & 12.9 & 49 & 7.9 & 8.8 \\
15 & 10.3 & 57 & 7.5 & 9.1 \\
20 & 10.2 & 57 & 7.5 & 10.5 \\
24 & 9.2 & 58 & 7.6 & 10.0 \\
Site PG1405, northern basin & & & & \\
0.1 & 16.2 & 55 & 8.3 & 9.4 \\
10 & 13.9 & 59 & 7.9 & 8.0 \\
15 & 10.0 & 56 & 7.5 & 8.1 \\
20 & 9.6 & 55 & 7.5 & 8.5 \\
21 & 9.8 & 56 & 7.7 & 7.8 \\
\hline
\end{tabular}

different facies (Astakhov, 1992; Kremenetski et al., 2003). The glacially formed hummock-and-lake landscapes around the Polar Urals are highly diverse, and include, for example, different types of moraines (Astakhov et al., 1999). At present, the Western Siberian lowlands are the world's largest high-latitude wetlands; they are characterized by diverse periglacial features, including permafrost, peat and swamp formation, and solifluction processes (Astakhov et al., 1999; Kremenetski et al., 2003).

The climate in this region is dry and cold, with a mean precipitation of 400 to $600 \mathrm{~mm} \mathrm{yr}^{-1}$ and mean temperatures for the coldest (January) and warmest (July and August) months of -16 to $-24^{\circ} \mathrm{C}$ and +4 to $+8^{\circ} \mathrm{C}$, respectively (Treshnikov, 1985). Lake LyadhejTo is ice-covered 8 to $9 \mathrm{mo}$ and becomes ice free by June. The vegetation in the lake catchment is dominated by grass and low shrub tundra.

\section{Material and Methods}

\section{CORING AND SEDIMENTOLOGY}

Sediment core PG1437 was taken in April 1999 in the northern basin of Lake Lyadhej-To in $21 \mathrm{~m}$ of water (Fig. 1). Coring was carried out using a piston corer (UWITEC Corp.; see Melles et al., 1994, for a detailed description of the coring technique). Core PG1437 is 11.80 $\mathrm{m}$ long. The basal part of the core (11.80-7.00 m) consists of a highly consolidated, pre-Holocene till (Fig. 2), which contains no diatoms. Therefore, the basal core section is not discussed further in this paper. The upper $7.00 \mathrm{~m}$ of core PG1437 consists of a stratified to laminated clayey-silty gyttja (Fig. 2) with an increased organic carbon content. A well-preserved diatom flora is present in the upper $6.70 \mathrm{~m}$ of the core.

\section{RADIOCARBON DATING}

Age control is provided by 14 radiocarbon dates on samples of cleaned terrestrial plant detritus and one piece of shrubwood (Table 2). Dating was carried out by accelerator mass spectroscopy (AMS) at the AMS laboratory in Kiel, Germany. The obtained radiocarbon ages were converted into calibrated ages (cal. yr B.P.) by using the INTCAL'98 calibration data set (Stuiver et al., 1998).

\section{DIATOM AND POLLEN SLIDE PREPARATION}

Diatom slides of 103 subsamples of $1 \mathrm{~cm}$ thickness were prepared using 0.2 to $1.5 \mathrm{~g}$ of freeze-dried bulk sediment that was treated 


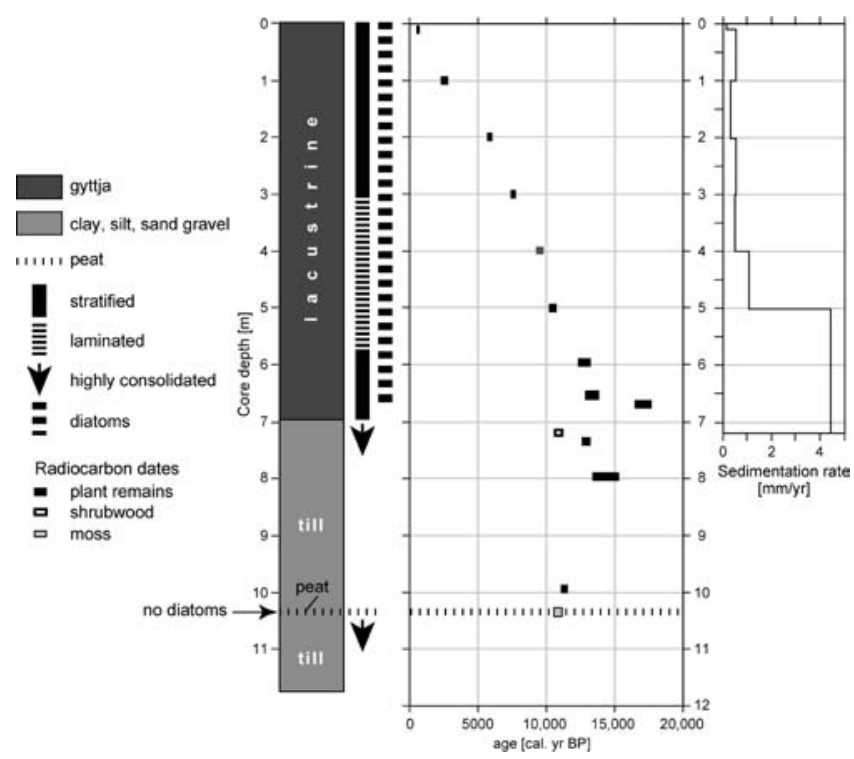

FIGURE 2. Sedimentology and chronology of core PG1437 from Lake Lyadhej-To (see also Table 2 for datings).

subsequently with hydrogen peroxide, hydrochloric acid, and nitric acid in order to remove all organic and carbonate components (Cremer et al., 2001). Slides were prepared employing the sedimentation tray method described by Battarbee (1973) and the high refraction mountant Naphrax ${ }^{\circledR}$ was used to mount the cover-glasses on slides. Diatom identification and counting were performed at $\times 1000$ magnification using a Zeiss-Axioplan-microscope equipped with differential interference contrast (Nomarski) optics. Generally, a minimum of 500 diatom valves were counted. The identification of diatom species was mainly based on Krammer and Lange-Bertalot (1991, 1999a, 1999b, 2000).

Pollen samples were prepared according to the method described in Andreev et al. (2001) and included treatment with fluoric and hydrochloric acid, acetolysis, staining with a solution of safranin, and sieving. Counting was performed at a magnification of $\times 400$. Generally, 300 to 400 pollen grains were counted on each slide.

\section{GEOCHEMICAL ANALYSES}

The total organic carbon content (TOC) was measured with a Metalyt-CS-1000-S apparatus (ELTRA Corp.), whereas the total sulphur (TS) and total carbon (TC) contents were analyzed with a CHNS-932 determinator (LECO Corp.). The calcium carbonate $\left(\mathrm{CaCO}_{3}\right)$ percentage of the samples was calculated from the carbonate content (difference between TC and TOC) and the atomic weights of the elements.

\section{Results}

\section{CHRONOLOGY}

Table 2 and Figure 2 report the radiocarbon dates obtained for core PG1437. Based on plant remains of aquatic origin, the base of the lacustrine sequence has an age of $\sim 17,000$ cal. yr B.P.; however, the age of a piece shrubwood in the uppermost till layer $(718 \mathrm{~cm}$ core depth) is $\sim 11,000$ cal. yr B.P. Consequently, the older dates obtained in the lacustrine core sequence at $597 \mathrm{~cm}, 653 \mathrm{~cm}$, and $671 \mathrm{~cm}$ core depth probably resulted from contamination with older, redeposited terrestrial plant detritus or "old" glacial meltwaters from the Ural Mountains (Table 2; Fig. 2). The assumed age of the onset of lacustrine sedimentation is also supported by a date obtained on moss detritus from a peat layer recovered in the lower third of the till sequence (Fig. 2). This peat was also formed at $\sim 11,000$ cal. yr B.P. (Table 2).

The sedimentary sequence in Lake Lyadhej-To and the available radiocarbon dates support the following conclusions: after the deposition of a basal till layer before 11,000 cal. yr B.P., a short-term, shallow-water environment developed and led to the formation of a thin peat layer at $\sim 11,000 \mathrm{cal}$. yr B.P. Subsequently, the shallow lake was rapidly filled up by more than $3 \mathrm{~m}$ of till. The onset of lacustrine sedimentation probably took place soon after the till deposition. Autochthonous planktic diatoms were deposited from $\sim 10,850 \mathrm{cal}$. yr B.P. The initial stage of the lake was characterized by a relatively high sedimentation rate (Fig. 2) probably supported by large inputs of allochthonous material, which is indicated by the relatively high percentages of re-deposited diatom valves (Fig. 3; Paralia siberica (Schmidt) Crawford et Sims) and pollen grains (Fig. 4).

\section{THE DIATOM RECORD}

In the Holocene sequence of core PG1437 a total of 153 diatom taxa from 42 genera were identified. Achnanthes (20 taxa), Fragilaria (17 taxa, including Pseudostaurosira, Staurosira and Staurosirella), and Navicula (19 taxa) are the most diverse genera. Diatom assemblages, however, are generally dominated by a few planktic species belonging to the genera Aulacoseira and Stephanodiscus and by small Staurosira and Staurosirella species (Fig. 3).

The diatom record of core PG1437 can be subdivided visually into seven biostratigraphical diatom units (informally named Diatom Unit A-G; Fig. 3) which are briefly described in chronological order.

\section{Diatom Unit A $(\sim 11,000-10,850$ cal. yr B.P.)}

The initial Holocene stage of Lake Lyadhej-To is characterized by the presence of Paralia siberica (Schmidt) Crawford et Sims, a taxon that is known only from Paleocene and Eocene deposits. Its occurrence indicates a relatively high terrestrial input into the lake basin, which is also suggested by the occurrence of re-deposited pollen (Fig. 4). The nearly complete absence of autochthonous planktic diatoms at the same time shows that there was no significant pelagic bioproductivity in the lake (Fig. 3).

\section{Diatom Unit B ( 10,850-9350 cal. yr B.P.)}

This unit shows the highest diatom valve concentrations $(2-5 \times$ $10^{9}$ valves per gram sed.) and is dominated by small Stephanodiscus taxa (S. hantzschii Grunow, S. minutulus (Kützing) Cleve et Möller, $S$. parvus Stoermer et Håkansson). Three other species, Aulacoseira islandica (Müller) Simonsen, Staurosira construens (Ehrenberg) Williams et Round and Staurosirella pinnata (Ehrenberg) Williams et Round are of minor importance. Towards the end of Unit B, the significance of these species gradually decreases, whereas the relative abundance of $A$. islandica increases.

\section{Diatom Unit C ( $\sim 9350-8650 \mathrm{cal}$. yr B.P.}

The diatom assemblage in this unit consists mainly of $A$. islandica, S. construens, S. pinnata, and the small Stephanodiscus species. Compared to the previous unit, the latter group occurs with distinctly lower relative abundances. Unit $\mathrm{C}$ has also the highest concentration of Cyclotella ocellata Pantocsek during the entire Holocene. The total diatom abundance is lower than $2 \times 10^{9}$ valves per gram of freeze-dried sediment (Fig. 3).

\section{Diatom Unit D ( 8650-7000 cal. yr B.P.)}

This period was characterized by further decrease of total diatom concentration and the Stephanodiscus group. The dominating diatom 
TABLE 2

Results of ${ }^{14} \mathrm{C}$ dating and calibrations in core PG1437

\begin{tabular}{|c|c|c|c|c|c|c|}
\hline Laboratory No & Depth $[\mathrm{cm}]$ & $\begin{array}{l}\text { Conventional } \\
{ }^{14} \mathrm{C} \text { age }[\mathrm{yr} \mathrm{BP}]\end{array}$ & $\begin{array}{c}{ }^{14} \mathrm{C} \text { error } \\
{[+/- \text { yr BP }]}\end{array}$ & Carbon dated & $\begin{array}{c}\text { Calibrated age } \\
\text { [cal. yr BP] }\end{array}$ & $\begin{array}{l}\text { Cal. age error } \\
{[+/- \text { yr BP }]}\end{array}$ \\
\hline KIA10040 & 9 & 690 & 30 & Plant detritus & 620 & 55 \\
\hline KIA8915 & 99 & 2460 & 40 & Plant detritus & 2550 & 200 \\
\hline KIA10041 & 201 & 5135 & 60 & Plant detritus & 5870 & 125 \\
\hline KIA8916 & 299 & 6730 & 70 & Plant detritus & 7580 & 105 \\
\hline KIA8920 & 399 & 8550 & 100 & Plant detritus & 9520 & 190 \\
\hline KIA8917 & 501 & 9230 & 90 & Plant detritus & 10450 & 230 \\
\hline KIA12131 & 597 & 10780 & 140 & Plant detritus & $12750^{*}$ & 390 \\
\hline KIA8759 & 653 & 11230 & 150 & Plant detritus & $13340^{*}$ & 450 \\
\hline KIA8760 & 671 & 14210 & 90 & Plant detritus & $17060 *$ & 510 \\
\hline KIA8761 & 718 & 9600 & 60 & Shrubwood & 10940 & 235 \\
\hline KIA12132 & 735 & 10940 & 90 & Plant detritus & $12910^{*}$ & 255 \\
\hline KIA12133 & 794 & 11850 & 80 & Plant detritus & $14370^{*}$ & 865 \\
\hline KIA 12134 & 994 & 9880 & 50 & Plant detritus & $11370^{*}$ & 180 \\
\hline KIA 12135 & 1035 & 9490 & 60 & Moss & 10830 & 265 \\
\hline
\end{tabular}

* Samples probably contaminated by older plant detritus.

Used calibration method: CALIB 4.3, Method I, intercept ages, errors at $2 \sigma$ probability (Stuiver et al., 1998).

species in Unit D is Aulacoseira subarctica (Müller) Harworth, whereas $S$. construens and S. pinnata are of secondary importance. Achnanthes spp. gradually increase in relative abundance in this unit.

Diatom Unit E ( 7000-2500 cal. yr B.P.)

This unit represents the longest period of relative stability in terms of the composition of the diatom community. The assemblage in Unit E is dominated by the periphytic species Staurosira construens and Staurosirella pinnata, and Achnanthes spp. (Fig. 3). Planktic diatoms generally play a minor role in this unit. The total diatom abundance has lowest values in this unit (below $1 \times 10^{9}$ valves per gram sed.).

Diatom Unit F ( 2500-0 cal. yr B.P.)

Similar to Unit D, A. subarctica dominates this unit, whereas the significance of $S$. construens, S. pinnata, and Achnanthes spp. is slightly reduced. The abundance of Cyclotella tripartita Håkansson increases at the end of Unit F. The total diatom valve concentration is slightly higher than in the previous unit. The youngest period in Lake Lyadhej-To (from $\sim 350$ cal. yr B.P.) shows a similar diatom assemblage to those of Unit E: planktic diatoms are of minor importance and S. construens, S. pinnata and Achnanthes spp. dominated (Fig. 3).

\section{THE GEOCHEMICAL AND POLLEN RECORDS}

The calcium carbonate and total sulphur content show distinct Holocene patterns, whereas changes in the total organic carbon content are relatively small (Fig. 4). Unit A has the lowest TOC content $(0.97$ $\pm 0.54 \%$ ). Maximum TOC values of $3.55 \pm 0.66 \%$ were recorded in Units $\mathrm{B}$ and $\mathrm{C}$, while Units $\mathrm{E}, \mathrm{D}$ and $\mathrm{F}$ are characterized by TOC values of $2.09 \pm 0.52 \%$. The TS content in core PG1437 also has its maximum in Unit $\mathrm{B}$, gradually decreases in Units $\mathrm{C}$ and $\mathrm{D}$ and remains extremely low from $\sim 7000$ cal. yr B.P. to the present. Furthermore, there is a clear calcium carbonate peak in early Unit B that subsequently rapidly decreases. From Unit C ( $\sim 9350$ cal. yr B.P.), the carbonate content in the core remains very low.

The abundance of the most important pollen groups is also displayed in Figure 4. Unit A is characterized by the dominance of spruce (Picea), herb (Cyperaceae, Poaceae, Artemisia spp., Thalictrum spp.), and redeposited pollen. These groups occur in low abundances in
Unit B, which is dominated by Betula alba pollen. The abundance of Betula alba decreases in Units $\mathrm{C}$ and D and remains relatively low during the mid and late Holocene with a maximum relative abundance of 20\% (Fig. 4). Spruce, herb, and pine (Pinus sylvestris) pollen are equally represented in these latter units. Betula nana pollen have a relative abundance between 10 and $20 \%$ throughout the entire sediment core.

\section{Discussion}

The diatom species records fit well with the main trends in the stratigraphy of selected geochemical and pollen parameters (Fig. 4). The TOC signature in core PG1437 shows a clear maximum in Units B and $\mathrm{C}$ that occurred contemporaneously with the maximum TS content, the total diatom concentration, and the proportion of planktic diatoms. This points to the presence of a thermal optimum northwest of the Ural Mountains during the early Holocene between $\sim 10,800$ and 8600 cal. yr B.P. that resulted in greater productivity in Lake Lyadhej-To. The relatively high TS content in Units B to D indicates the dominance of anoxic conditions on the lake bottom during this period as a result of increased deposition of algal and terrestrial organic detritus. However, C:N ratios between 8:1 and 16:1 support the idea that most of the TOC in core PG1437 is derived from algal productivity in Lake Lyadhej-To. High sedimentation of organic matter on the lake bottom causes decomposition processes that use up oxygen and result in an increased production of sulphides. Further decrease of oxygen could also be caused by an increase in thermal stratification as a result of warmer temperatures or decreased influence of wind (Moser et al., 2002). The high deposition of authigenic carbonate in Unit B likely reflects alkaline $\mathrm{pH}$ conditions possibly resulting from increased photosynthesis in Lake Lyadhej-To that allowed the precipitation and preservation of calcium carbonate (Fig. 4). $\delta^{18} \mathrm{O}$ values of carbonate range from -16 to $-12 \%$ PDB before $\sim 9500$ cal. yr B.P. and from -10 to $-7 \%$ PDB between $\sim 9500$ and $\sim 8800$ cal. yr B.P., indicating distinct hydrological changes at this transition. An early Holocene climatic optimum is also supported by the pollen record, which indicates an increase in the abundance of Betula alba. A peak in Betula alba in the early Holocene has also been reported in many other pollen records from northern Eurasian regions (e.g., Kaakinen and Eronen, 2000; Pitkänen et al, 2002; Solovieva and Jones, 2002), among them 


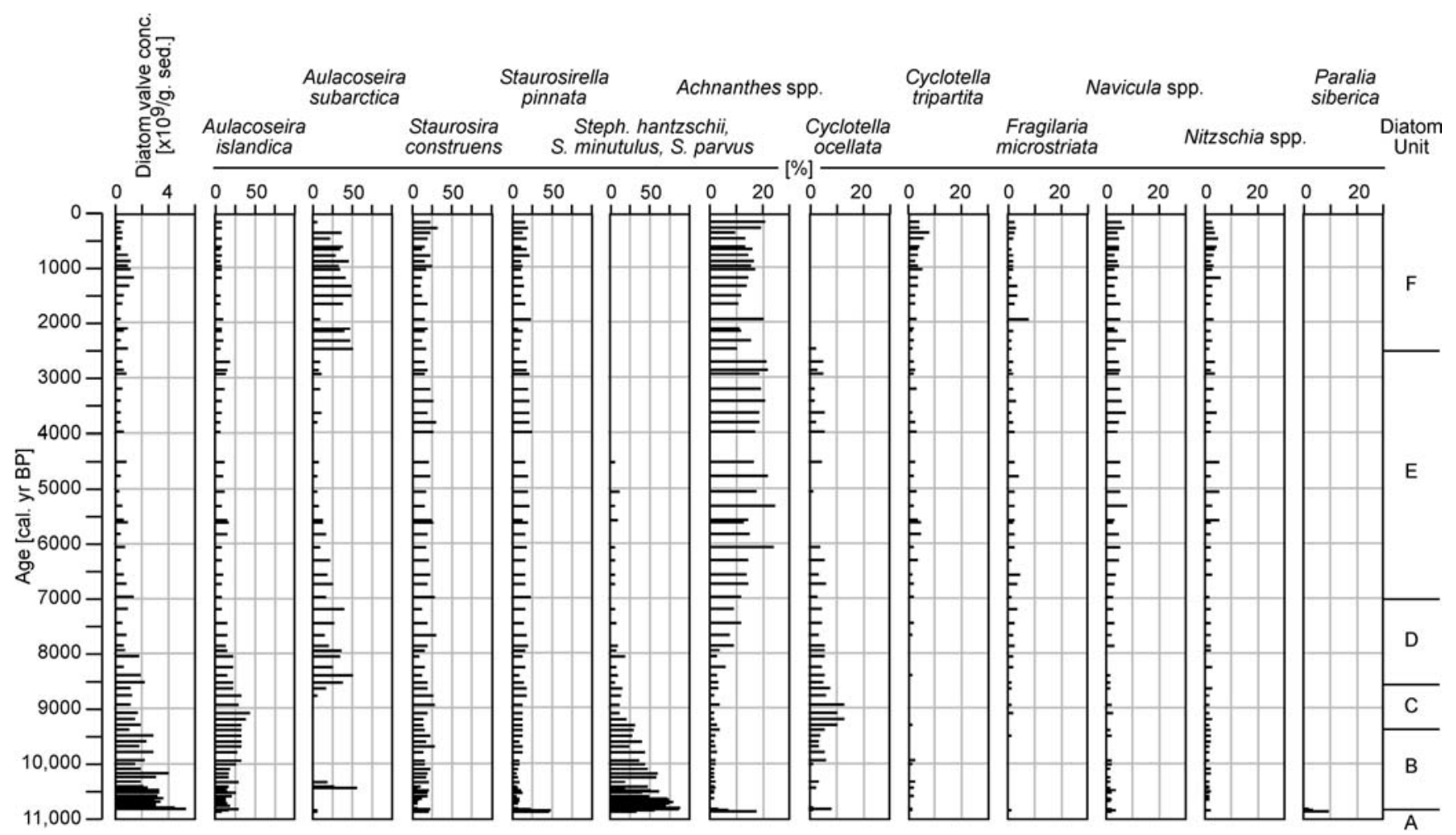

FIGURE 3. Holocene diatom stratigraphy of core PG1437 from Lake Lyadhej-To. Diatom units are defined based on major changes in the diatom assemblage.

a sedimentary profile at Cape Shpindler, northern Yugorski Peninsula, which is closely located to Lake Lyadhej-To (Andreev et al., 2001). These records support generally warm climatic conditions during the early Holocene across northern latitudes in West Siberia. Productivity rapidly decreased in Units $\mathrm{C}$ and $\mathrm{D}$, which indicates a deterioration in climatic conditions. This is also evidenced by decreases in TOC content, total diatom valve concentration, and proportions of planktic diatoms and Betula alba pollen (Fig. 4). The distinct decrease in TS content in Units C and D might indicate improved ventilation of bottom waters and hence reduced anaerobic decomposition of organic matter. Unit E, lasting from $\sim 7000$ to $\sim 2500$ cal. yr B.P., probably reflects the coolest period in the northern Polar Urals during the Holocene. All sedimentary indicators reflecting productivity and warmer temperatures (TOC, total diatom concentration, planktic diatom abundance) show minimum values, whereas the abundance of spruce (Picea), pine (Pinus), and herb pollen distinctly increase. Climatic and environmental conditions likely improved again during Unit $\mathrm{F}$ indicated by a distinct increase of the relative abundance of planktic diatoms, mainly A. subarctica (Figs. 3, 4). As well, the total abundance of organic carbon and concentration of diatom valves slightly increase, supporting a climatic amelioration. Increased summer temperatures might have reduced the extent of ice cover on Lake Lyadhej-To and, hence, led to an extended open water season, higher water temperatures and stronger diatom growth in the lake's pelagic zone (Smol, 1988; Douglas and Smol, 1999; Cremer et al., 2001; Rühland et al., 2003). Vegetation during this period probably continued to be mainly Arctic tundra with few spots covered by conifer forests. However, towards the end of Unit F (from $\sim 350$ cal. yr B.P.) diatom and pollen data reflect again a cooling that led to reduced diatom productivity and the dominance of herb vegetation in the catchment of the lake.

Based on the data presented in the Figures 3 and 4, the Holocene limnological history of Lyadhej-To can be subdivided into five limnological episodes (Fig. 5).

Episode I ( 11,000-10,850 cal. yr B.P.)

During this period, consistent with the Preboreal (Haas et al., 1998; Pitkänen et al., 2002), Lake Lyadhej-To was characterized by the deposition of mainly clastic material from glacial meltwaters which would have been draining off the Ural Mountains. This is also indicated by the occurrence of redeposited pollen and diatoms in sediments from this period. The absence of autochthonous algal growth and terrestrial organic detritus, indicated by low TOC content, during this initial episode point to turbid and nutrient-poor lake conditions.

The catchment vegetation was dominated by plants typical for Arctic tundra (Fig. 4) which indicate that a cool and dry climate existed northwest of the Ural Mountains. These findings are similar to results from other localities from West Siberia (e.g., Hahne and Melles, 1997; Andreev et al., 2001; Pitkänen et al., 2002).

\section{Episode II ( 10,850-8650 cal. yr B.P.)}

The Boreal in northern Siberia is characterized by the highest TOC and total diatom concentrations, and a distinct dominance of planktic diatoms, indicating that Episode II has the longest growing season, lowest lake-ice coverage and highest bioproductivity in Lake Lyadhej-To of all five episodes (Fig. 3). This period is undoubtedly the warmest postglacial episode and marks the Holocene climatic optimum in northern Eurasia (MacDonald et al., 2000; Andreev et al., 2001).

The diatom assemblage is initially predominated by Stephanodiscus taxa, which later co-occur with A. islandica and C. ocellata (Fig. 3). All three Stephanodiscus taxa are alkalibiontic species, which occur 


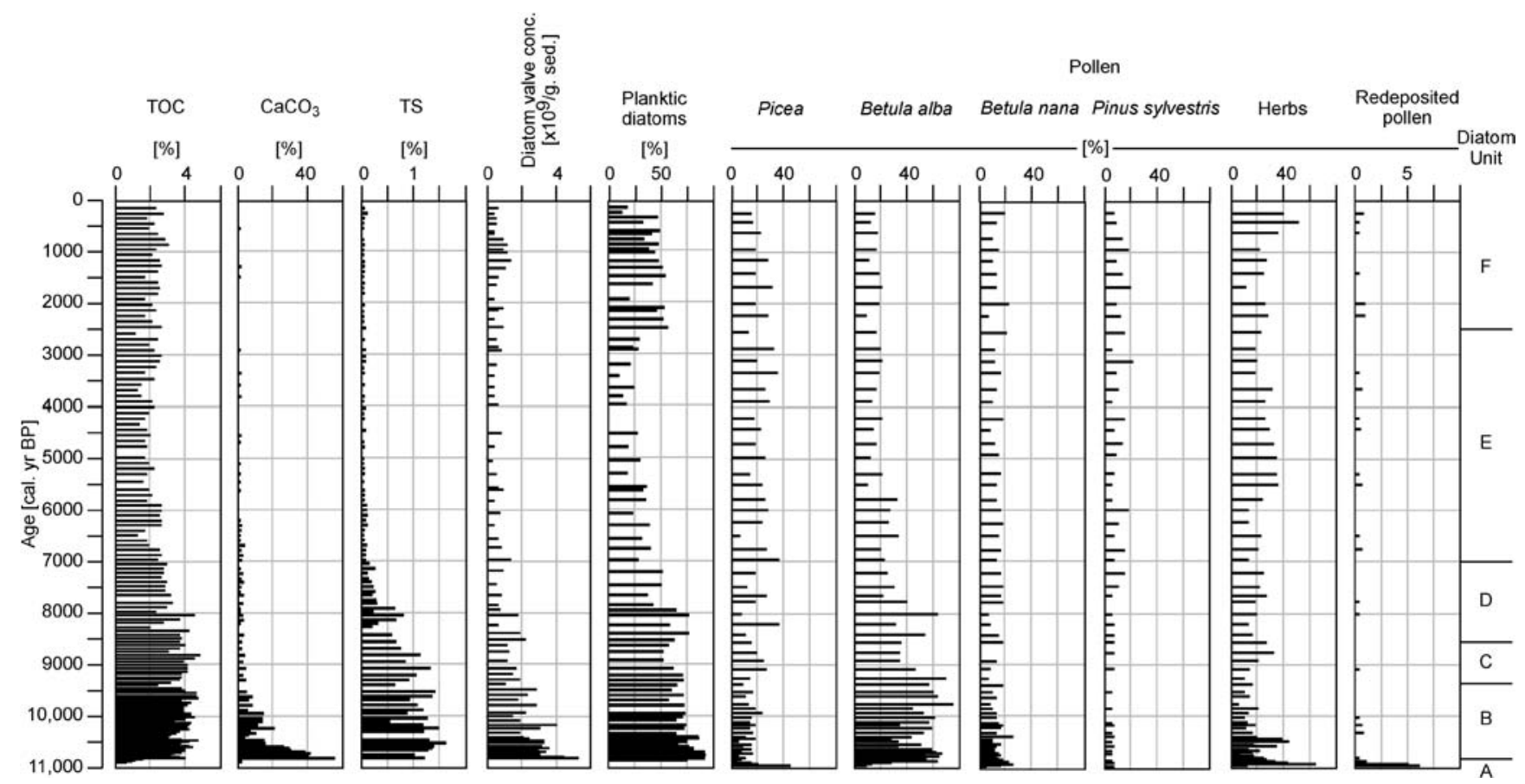

FIGURE 4. Selected geochemical and palynological parameters in core PG1437 from Lake Lyadhej-To compared to the total diatom valve concentration and the proportion of planktic diatoms. Herb pollen counts include Cyperaceae, Poaceae, Ericales, Artemisia, Thalictrum, and Polygonum.

exclusively at $\mathrm{pH}$ values $>7$ (van Dam et al., 1994). High calcium carbonate precipitation at the beginning of Episode II support high alkalinity at this time (Fig. 4). Stephanodiscus hantzschii and related species are also known as eutraphentic species (van Dam et al., 1994) which support the presence of nutrient-rich conditions in Lake Lyadhej-To during Boreal summers, possibly caused by increased terrestrial nutrient input as a consequence of less and shorter ice and snow cover. Bottom waters and sediments were probably anoxic, as reflected by the remarkable sulphur deposition, suggesting stratification of the water column. The dominance of A. islandica and C. ocellata from $\sim 10,000$ cal. yr B.P.- both are classified as circumneutral and alkaliphilous taxa, respectively (van Dam et al., 1994) - and the contemporaneous decrease of Stephanodiscus abundance might indicate a slight shift towards lower $\mathrm{pH}$ in Lake Lyadhej-To. The lower $\mathrm{CaCO}_{3}$ content in the core from $\sim 10,000$ cal. yr B.P. supports lower alkalinity of the lake water or changed diagenetic conditions within the upper sediment layers. The simultaneous gradual decrease of both the total sulphur content and the increase in Aulacoseira abundance towards the end of Episode II (Figs. 3, 4) demonstrate that both parameters likely were linked together and might reflect an increased ventilation possibly caused by increased wind activity and, consequently, mixing of the water column.

The pollen assemblage during Episode II was dominated by tree birch pollen (Fig. 4), indicating that the region was widely covered by birch forests during Preboreal and early Boreal times. This interpretation is in agreement with other records from the region (e.g., Andreev et al., 2001; Solovieva and Jones, 2002), confirming that the birch treeline was located farther north during Episode II than it is today (Khotinskiy, 1984; MacDonald et al., 2000). According to Kremenetski et al. $(1998,2003)$ the period between 9000 and $7500{ }^{14} \mathrm{C}$ yr B.P., corresponding to $\sim 10,200$ to 8500 cal. yr B.P., was most favorable for tree growth in northern Russia. Another indicator that Lake Lyadhej-To was surrounded by forests is the relatively low abundance of the fragilarioid diatoms Staurosirella pinnata and Staurosira construens (Fig. 3), which, according to Laing and Smol
(2000), generally have low abundances in forested lakes of high latitudes.

\section{Episode III ( 8650-7000 cal. yr B.P.)}

This period, representing the early and middle Atlantic, has to be regarded as a transition between the climatic optimum during Episode II and the long period of relatively cooler climatic conditions of the following Episode IV. All biological and geochemical records point to a deterioration of the climate and cooler temperatures than before. The deposition of diatom valves, TOC and sulphur gradually decreased (Fig. 4) confirming a lower bioproductivity in Lake Lyadhej-To. The abundance of Stephanodiscus further decreased and A. islandica was replaced by $A$. subarctica (Fig. 3), probably proving that the lake water showed a slight tendency to further acidification. Aulacoseira subarctica is characterized as an acidophilous diatom (van Dam et al., 1994), indicating a pH in Lake Lyadhej-To below 7. During Episode III there was also a distinct gradual increase of the relative abundance of Achnanthes spp. which might be a result of decreased availability of open water habitats as a result of extended or prolonged ice cover on Lake Lyadhej-To.

The pollen assemblage in Episode III shows a decline of birch pollen and a contemporaneous rise of spruce and pine pollen (Fig. 4) during the early Atlantic indicating that the birch-dominated forests of the climatic optimum were replaced by conifer-dominated forests. A similar pattern is also reported from other sites in northern Siberia (Hahne and Melles, 1997; Pitkänen et al., 2002).

\section{Episode IV ( 7000-2500 cal. yr B.P.)}

The mid-Holocene in the northern Ural Mountains was a relatively long and climatically stable period with minor variation in the diatom, pollen and geochemical records. Lowest concentrations of TOC and diatom valves in sediments of Episode IV confirm that the terrestrial nutrient influx was decreased and, consequently, bioproductivity in 


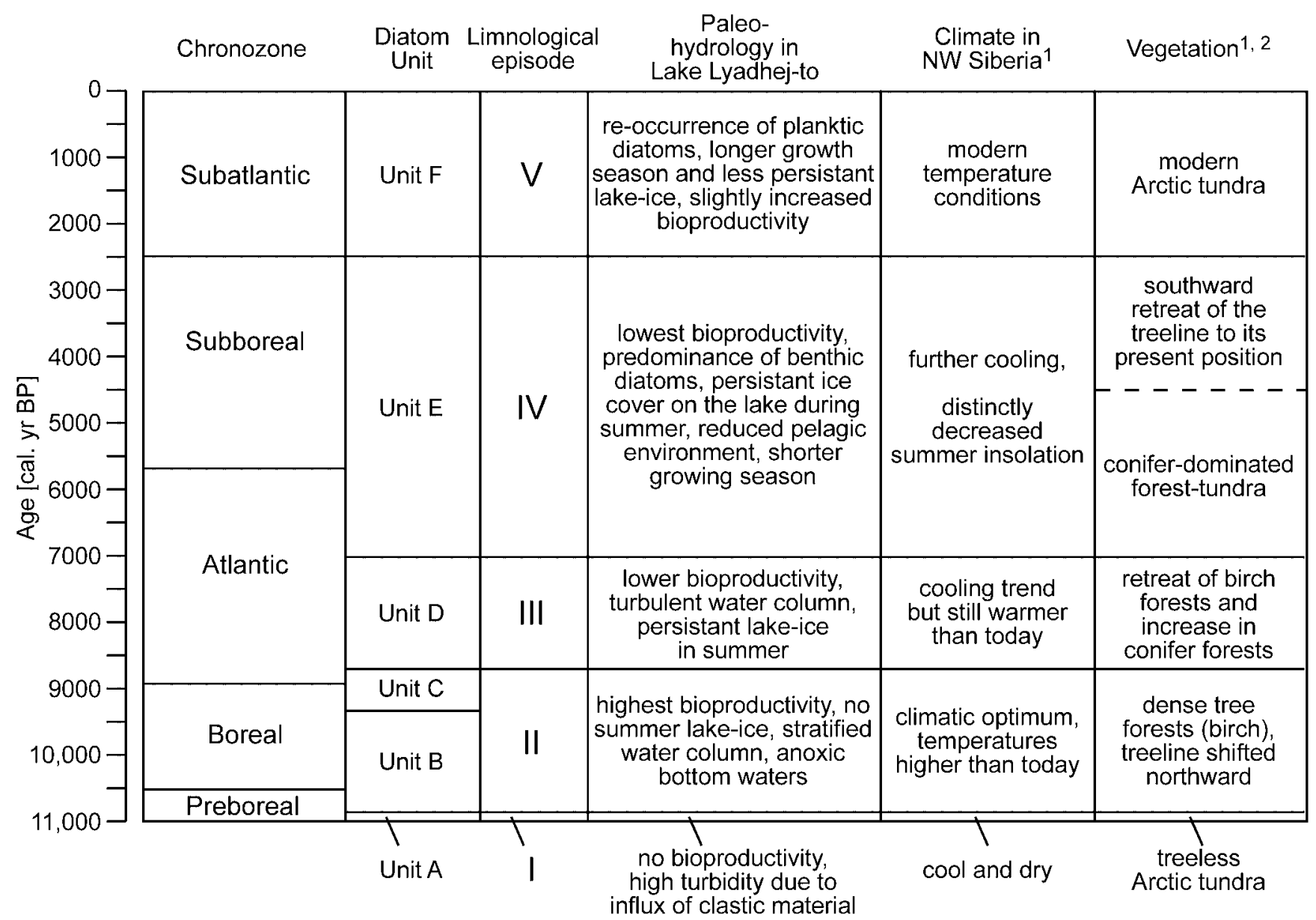

FIGURE 5. Summary of limnological and climatic changes reflected in core PG1437 from Lake Lyadhej-To. Chronozone boundaries according

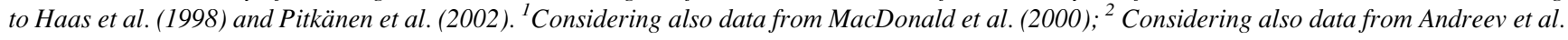
(2001).

Lake Lyadhej-To was low (Fig. 4). The relative increase of benthic diatoms (Achnanthes, Navicula, Staurosira, Staurosirella) and the lower proportion of planktic diatoms point to relatively short growing seasons and longer persistence of ice on the lake during summer leading at least to an ice-free moat of the lake (Smol, 1988; Cremer et al., 2001). There is no evidence that the acidity in Lake Lyadhej-To changed from Episode III. The most abundant taxa during Episode IV, Staurosirella pinnata and Staurosira construens, are alkaliphilous taxa (van Dam et al., 1994).

The vegetation during Episode IV was relatively uniform and can be characterized as a mix of grass-low shrub tundra and Picea-PinusBetula forests. In the middle of this period, corresponding to the Atlantic-Subboreal transition, herb pollen became more significant (Fig. 4) reflecting that Arctic tundra vegetation was more widespread than before. Synchronous increases in the abundance of Staurosirella pinnata and Staurosira construens further supports an increase in tundra vegetation at this time (Laing and Smol, 2000). This vegetational shift, occurring at the Atlantic-Subboreal boundary, is also visible in a profile recovered from Yugorski Peninsula some 100 $\mathrm{km}$ north of Lyadhej-To (Andreev et al., 2001) and in adjacent regions (e.g., Pitkänen et al., 2002). From $\sim 4500$ cal. yr B.P., the vegetation in the Lyadhej-To region was probably similar to the modern vegetation cover. The mid-Holocene was a period of rapid change of treeline in northern Siberia, which resulted in a southward shift of treeline to its present position (Kaakinen and Eronen, 2000; MacDonald et al., 2000).
Episode V ( 2500 cal. yr B.P. to present $)$

The Subatlantic period initially shows some distinct changes in the diatom record which might have been a result of altered limnological conditions. There is an increase in both the TOC and total diatom valve contents indicating slightly higher nutrient supply and bioproductivity in Lake Lyadhej-To. Warmer temperatures are also indicated by the re-occurrence of A. subarctica, which is the dominant planktic diatom in the Subatlantic, and slightly lower relative abundances of benthic diatoms (Figs. 3, 4). Both observations suggest an extended growing season during Subatlantic summers, possibly accompanied by reduced and/or shorter ice cover on the lake. These conditions, as well as a relatively low lakewater $\mathrm{pH}$, enabled $A$. subarctica to increase in abundance. A low lakewater $\mathrm{pH}$ is also supported by the occurrence of $C$. tripartita, another acidophilous diatom.

The Subatlantic pollen record from Lake Lyadhej-To initially shows no changes, but from $\sim 1000$ cal. yr B.P., there is an increase in the abundance of herbs and a decrease in the relative abundance of Picea and Pinus pollen (Fig. 4), reflecting the dominance of arctic tundra vegetation and probably the farther southward shift of treeline. This trend is less notable in the diatom record, but is reflected in a decreased total diatom concentration and proportion of planktic diatoms.

A distinct late Holocene climatic amelioration, as reflected by the diatom record from Lake Lyadhej-To, is contrary to most other available paleoecological records from northern Siberia which, 
however, are based mostly on vegetation studies. All these studies generally report a treeline retreat in northern Eurasia from $\sim 4000 \mathrm{cal}$. yr B.P. and a replacement of boreal forests by arctic tundra vegetation (Khotinskiy, 1984; MacDonald et al., 2000). However, the climatic deterioration that is recorded since the Atlantic-Subboreal boundary was regularly interrupted by warmer phases during which boreal forests remigrated to the north (Khotinskiy, 1984).

\section{Concluding Remarks}

Diatom, geochemical, and pollen records in sediment core PG1437 reflect both limnological and climatic trends around Lake Lyadhej-To during the past 11,000 cal. yr B.P. (Fig. 5). These trends are indicated by changes in diatom assemblage composition, which document long-term changes in lakewater $\mathrm{pH}$, lake-ice cover, and habitat availability. A climatic optimum from $\sim 10,850$ to 8650 cal. yr B.P. is clearly confirmed by the diatom record, which indicates rapid climatic warming after the last deglaciation. The pollen record also indicates changes in the vegetation cover northwest of the Ural Mountains, which are in good accordance with previously published results (see review by MacDonald et al., 2000). According to MacDonald et al. (2000) northern Eurasia was forested to or near the current arctic coastline between $\sim 9000$ and $\sim 7000{ }^{14} \mathrm{C}$ yr B.P., corresponding to $\sim 10,000$ to $7800 \mathrm{cal}$. yr B.P. All available vegetation data confirm a southward treeline shift and cooler temperatures since the mid-Holocene in northern Eurasia (e.g., Andreev et al., 2001; Khotinskiy, 1984).

However, taking into account the large surface of northern Eurasia the available data base, particularly on aquatic biota (e.g., diatoms, chironomids), is rather small and has to be improved in future. This might lead to a more detailed picture of past climatic and environmental changes and also reveal regional differences and peculiarities in limnological conditions and treeline positions.

\section{Acknowledgments}

The present study is a contribution to the European Commission project Ice Sheets and Climate in the Eurasian Arctic at the Last Glacial Maximum (Eurasian Ice Sheets, Svendsen et al., 1999) which is coordinated by the European Science Foundation Programme QUEEN (Quaternary Environments of the Eurasian North). The valuable and detailed comments of two anonymous reviewers are greatly acknowledged.

\section{References Cited}

Andreev, A. A., Manley, W. F., Ingølfsson, Ó., and Forman, S. L., 2001: Environmental changes on Yugorski Peninsula, Kara Sea, Russia, during the last 12,800 radiocarbon years. Global and Planetary Change, 31: 255-264.

Astakhov, V., 1992: The last glaciation in West Siberia. Sveriges Geologiska Undersökning Serie Ca, 81: 21-30.

Astakhov, V. I., Svendsen, J. I., Matiouchkov, A., Mangerud, J., Maslenikova, O., and Tveranger, J., 1999: Marginal formations of the last Kara and Barents ice sheets in northern European Russia. Boreas, 28: 23-45.

Battarbee, R. W., 1973: A new method for estimation of absolute microfossil numbers, with reference especially to diatoms. Limnology and Oceanography, 18: 647-653.

Cremer, H., Wagner, B., Melles, M., and Hubberten, H.-W., 2001: The postglacial environmental development of Raffles $\mathrm{S} \emptyset$, East Greenland: inferences from a 10,000 year diatom record. Journal of Paleolimnology, 26: 67-87.

Douglas, M. S. V. and Smol, J. P., 1999: Freshwater diatoms as indicators of environmental change in the High Arctic. In Stoermer,
E. F. and Smol, J. P. (eds.), The Diatoms: Applications for the Environmental and Earth Sciences. Cambridge: Cambridge University Press, 227-244.

Haas, J. N., Richoz, I., Tinner, W., and Wick, L., 1998: Synchronous Holocene climatic oscillations recorded on the Swiss Plateau and at timberline in the Alps. The Holocene, 8: 301-309.

Hahne, J. and Melles, M., 1997: Late- and post-glacial vegetation and climate history of the south-western Taymyr Peninsula, central Siberia, as revealed by pollen analysis of a core from Lama Lake. Vegetation History and Archaeobotany, 6: 1-8.

Hall, R. I. and Smol, J. P., 1999: Diatoms of indicators of lake eutrophication. In Stoermer, E. F. and Smol, J. P. (eds.). The Diatoms: Applications for the Environmental and Earth Sciences. Cambridge: Cambridge University Press, $128-168$.

Hermichen, W.-D. and Wischer, F., 1999: Eurasian Ice Sheets: Expedition to the lake Lyadhej-To (Polar Urals), July-August 1998. Reports on Polar Research, 315: 261-268.

Hermichen, W.-D., Gierlichs, A., Wischer, F., and Bolshiyanov, D., 2000: German-Russian expedition POLAR URAL '99. Reports on Polar Research, 354: 271-303.

Kaakinen, A. and Eronen, M., 2000: Holocene pollen stratigraphy indicating climatic and tree-line changes derived from a peat section at Ortino, in the Pechora lowland, northern Russia. The Holocene, 10: 611-620.

Khotinskiy, N. A., 1984: Holocene vegetation history. In Velichko, A. A. (ed.), Late Quaternary Environments of the Soviet Union. Minneapolis: University of Minnesota Press, 179-200.

Kienel, U., 1999: Late Weichselian to Holocene diatom succession in a sediment core from Lama Lake, Siberia and presumed ecological implications. In Kassens, H., Bauch, H. A., Dmitrenko, I., Eicken, H., Hubberten, H.-W., Melles, M., Thiede, J., and Timokhov, L. (eds.), Land-Ocean Systems in the Siberian Arctic: Dynamics and History. Berlin: Springer-Verlag, 377-405.

Kienel, U., Siegert, C., and Hahne, J., 1999: Late Quaternary palaeoenvironmental reconstructions from a permafrost sequence (North Siberian Lowland, SE Taymyr Peninsula) - a multidisciplinary case study. Boreas, 28: 181-193.

Krammer, K. and Lange-Bertalot, H., 1991: Bacillariophyceae 4. Teil: Achnanthaceae. In Ettl., H., Gärtner, G., Gerloff, J., Heynig, H. and Mollenhauer, D. (eds.), Süßwasserflora von Mitteleuropa, Band 2/4. Heidelberg: Gustav Fischer Verlag. 437 pp.

Krammer, K. and Lange-Bertalot, H., 1999a: Bacillariophyceae 1. Teil: Naviculaceae. In Ettl., H., Gerloff, J., Heynig, H. and Mollenhauer, D. (eds.), Süßwasserflora von Mitteleuropa, Band 2/1. Heidelberg: Gustav Fischer Verlag. 876 pp.

Krammer, K. and Lange-Bertalot, H., 1999b: Bacillariophyceae 2. Teil: Bacillariaceae, Epithemiaceae, Surirellaceae. In Ettl., H., Gerloff, J., Heynig, H. and Mollenhauer, D. (eds.), Süßwasserflora von Mitteleuropa, Band 2/2. Heidelberg: Gustav Fischer Verlag. $611 \mathrm{pp}$.

Krammer, K. and Lange-Bertalot, H., 2000: Bacillariophyceae 3. Teil: Centrales, Fragilariaceae, Eunotiaceae. In Ettl., H., Gerloff, J., Heynig, H. and Mollenhauer, D. (eds.), Süßwasserflora von Mitteleuropa, Band 2/3. Heidelberg: Gustav Fischer Verlag. 599 pp.

Kremenetski, C. V., Sulerzhitsky, L. D., and Hantemirov, R., 1998: Holocene history of the northern range limits of some trees and shrubs in Russia. Arctic, Antarctic, and Alpine Research, 30: 317-333.

Kremenetski, K. V., Velichko, A. A., Borisova, O. K., MacDonald, G. M., Smith, L. C., Frey, K. E., and Orlova, L. A., 2003: Peatlands of the Western Siberian lowlands: current knowledge on zonation, carbon content and Late Quaternary history. Quaternary Science Reviews, 22: 703-723.

Laing, T. E. and Smol, J. P., 2000: Factors influencing diatom distributions in circumpolar treeline lakes of northern Russia. Journal of Phycology, 36: 1035-1048.

MacDonald, G. M., Velichko, A. A., Kremenetski, C. V., Borisova, O. K., Goleva, A. A., Andreev, A. A., Cwynar, L. C., Riding, R. T., Forman, S. L., Edwards, T. W. D., Aravena, R., Hammarlund, D., Szeicz, J. M., and Gattaulin, V. N., 2000: Holocene treeline history 
and climate change across northern Eurasia. Quaternary Research, 53: $302-211$.

Mangerud, J., Astakhov, V. I., Murray, A., and Svendsen, J.-I., 2001: The chronology of a large ice-dammed lake and the Barents-Kara Ice Sheet advances, Northern Russia. Global and Planetary Change, 31: 321-336.

Mangerud, J., Astakhov, V., and Svendsen, J.-I., 2002: The extent of the Barents-Kara ice sheet during the Last Glacial Maximum. Quaternary Science Reviews, 21: 111-119.

Melles, M., Kulbe, T., Overduin, P. P., and Verkulich, S., 1994: The expedition Bunger Oasis 1993/94 of the AWI Reearch Unit Potsdam. Reports on Polar Research, 148: 27-80.

Michelutti, N., Laing, T. E., and Smol, J. P., 2001: Diatom assessment of past environmental changes in lakes located near teh Noril'sk (Siberia) smelters. Water, Air, and Soil Pollution, 125: 231-241.

Moser, K. A., Smol, J. P., MacDonald, G. M., and Larsen, C. P. S., 2002: $19^{\text {th }}$ Century eutrophication of a remote boreal lake: a consequence climate warming? Journal of Paleolimnology, 28: 269-291.

Pitkänen, A., Turunen, J., Tahvanainen, T., and Toloenen, K., 2002: Holocene vegetation history from Salym-Yugan Mire Area, West Siberia. The Holocene, 12: 353-362.

Rühland, K., Priesnitz, A., and Smol, J. P., 2003: Paleolimnological evidence from diatoms for recent environmental changes in 50 lakes across Canadian Arctic treeline. Arctic, Antarctic, and Alpine Research, 35: 110-123.

Smol, J. P., 1988. Paleoclimate proxy data from freshwater arctic diatoms. Verhandlungen der Internationalen Vereinigung der Limnologie, 23: 837-844.

Smol, J. P. and Cumming, B. F., 2000: Tracking long-term changes in climate using algal indicators in lake sediments. Journal of Phycology, 36: 986-1011.

Solovieva, N. and Jones, V.J., 2002: A multiproxy record of Holocene environmental changes in the central Kola Peninsula, northwest Russia. Journal of Quaternary Science, 17: 303-318.

Svendsen, J. I., Astakhov, V. I., Bolshiyanov, D. I., Demidov, I., Dowdeswell, J. A., Gataullin, V., Hjort, C., Hubberten, H.-W., Larsen, E., Mangerud, J., Melles, M., Möller, P., Saarnisto, M., and Siegert, M., 1999: Maximum extent of the Eurasian ice sheets in the Barents and Kara Sea region during the Weichselian. Boreas, 28: 234-242.

Stuiver, M., Reimer, P. J., Bard, E., Beck, J. W., Burr, G. S., Hughen, K. A., Kromer, B., McCormack, G., van der Plicht, J., and Spurk, M., 1998: INTCAL '98 radiocarbon age calibration, 24,000-0 cal BP. Radiocarbon, 40: 1041-1083.

Treshnikov A. F., 1985: Atlas of the Arctic. Moscow: Main Department of Geodesy and Cartography under the Council of Ministers of the USSR. 204 pp. (In Russian.)

Van Dam, H., Mertens, A., and Sinkeldam, J., 1994. A coded checklist and ecological indicator values of freshwater diatoms from the Netherlands. Netherlands Journal of Aquatic Ecology, 28: 117-133.

Wischer, F., Andreev, A., Hermichen, W.-D., and Hubberten, H.-W., 2001: The late-Quaternary environmental History of the Western Foreland of the Polar Urals inferred from lake sediment studies. In: EUG XI, 8-12 April 2001, Programme and abstract volume. Strasbourg: European Union of Geosciences, 217.

Ms submitted August 2002 Revised ms submitted May 2003 